\title{
'From History Project to Transdisciplinary Research': District Six as a case study
}

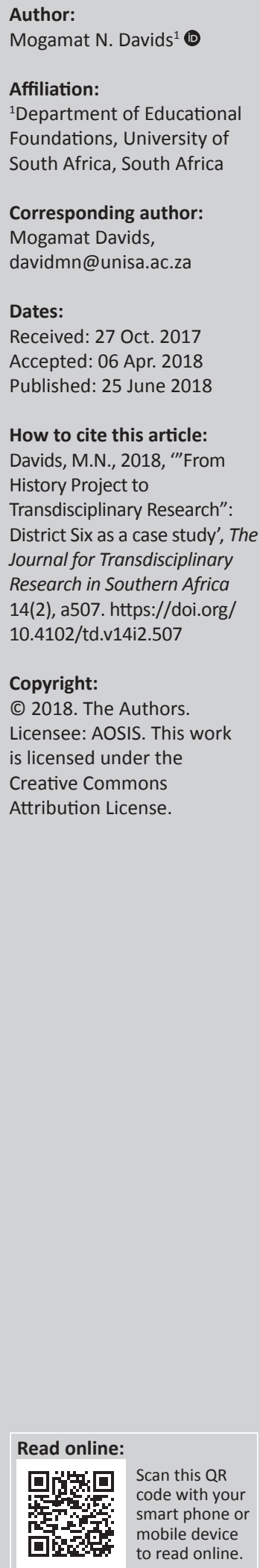

\begin{abstract}
This article expounds how a National Research Foundation (NRF) history project evolved into a transdisciplinary study. The article develops a case in favour of transdisciplinary research as a departure from strict discipline-based inquiry. The project involves collaborative research with Master's students and researchers located at five South African universities. The aim of this article is to evaluate the project as a transdisciplinary case study, intending to focus on its emergence as a history-based discipline, evolving into a transdisciplinary project. It also explores the epistemological value of transdisciplinary research as a knowledge production methodology in the context of the demand for a decolonised curriculum in South Africa. The article is set in the context of a NRF project with a spatiotemporal focus on the District Six forced removals during the colonial-apartheid period. A qualitative instrumental case study design guided the data collection and analyses. Participants' project proposal texts were used as data. The results show, firstly, that transdisciplinarity is manifested in a wide range of titles and disciplines; secondly, a myriad of conceptual frameworks emerged from the data; and thirdly, a broad spectrum of research approaches emerged, mainly qualitative. Transdisciplinarity focuses on the 'subject' and the 'hidden middle' as domain where alternative philosophical research orientations are explored. Transdisciplinarity can be regarded as 'Ubuntu' research, given the common concern to bring out the 'voice' of the subaltern and a rejection of separation of humans into 'racial' classifications. As 'Ubuntu research', transdisciplinary research rejects an atomistic understanding of reality that excludes the human subject and a separation between human and nature.
\end{abstract}

\section{Introduction}

Political transformation in South Africa had significant epistemological implications. The transition from apartheid to democracy implied a political shift in power that created epistemological space to challenge colonial-apartheid historical narratives. According to Foucault, a shift in political power is potentially a transformation in regimens of truth because power and knowledge are inseparable (Dreyfus \& Rabinow 1982). Considering the inseparability of knowledge and power, constructions of knowledge are viewed as discourse formations articulated as effects of power (Foucault 1991). During the post-apartheid transition period, knowledge became a highly contested terrain. Notwithstanding the contestations around the terms 'colonisation' and 'decolonisation', official South African history was written from a colonial-apartheid perspective, which imposed a Eurocentric-Afrikaner nationalist view of the past, rendering the historically oppressed communities invisible or marginalised. According to Mignolo, geo- and body-politics of knowledge has been hidden from the self-serving interest of Western epistemology and the task of decolonial thinking is to unveil the epistemic silences of Western epistemology and affirming the epistemic rights of the racially devalued (Mignolo 2009:3). In the South African context, there is still an imbalance between Euro-Afrikaner centric and an 'Africanised/decolonised/indigenize' historiography. After 23 years into democracy, the continuation of a dominant colonial-apartheid curriculum and an infuriating annual university fee increment resulted in the \#FeesMustFall Movement: a national student activist movement that demanded a quality, decolonised and free education (Langa 2017). While the demand for free higher education elicited a positive political response from former President Jacob Zuma (Hunter 2017), the demand for quality and a decolonised curriculum remains an inescapable imperative in the educational sector.

The theoretical richness in South African historiography is destined to intensify with the increasing demand for a decolonised narrative. Traditionally, history has been written from particular ideological positions: from colonial English liberalism to radical Marxism, to Afrikaner 
nationalist writing (Wright 1977). Visser (2004) traced certain trends in South African historiography beyond the traditional schools towards a 'Social history', as demonstrated in the work of the Wits History Workshop and University of Cape Town's memory and oral history projects. These initiatives begun to recognise the history of the voices of previously excluded communities (Visser 2004). These changes in South African historiography demonstrate how history as a discipline has gradually evolved towards transdisciplinary research and potentially as an agent for decolonisation, as this article will show.

This article illuminates the evolution of a District Six history project, into transdisciplinary research, involving multiple researchers working in different universities in South Africa. The article explains how a National Research Foundation (NRF) project grew into a transdisciplinary study, as it evolved from its discipline-specific base, to engage relevant and complex research questions. As a post-apartheid study, the project sets out to record forgotten, unrecorded and suppressed memories of a previously disadvantaged community. Interestingly, all participants or researchers in the project were either born there or have close personal relations with people from the District Six community. Postapartheid historians and other social scientists are constantly challenged to address the biased representation and almost invisibility of historically oppressed communities in the school and higher education curriculum. Official opportunities to address the epistemic injustices of the past are presented by the government through the NRF's funding platform, which gave birth to the project: Remembering District Six: Lest it be forgotten. District Six was chosen as a research focus for its richness in symbolism, historical material and pedagogical potential. District Six symbolises the physical and psychological scars left behind by apartheid's Group Areas Act (1950). The South African historical landscape is strewn with unrecorded memories, untold stories and experiences of forced removals of communities such as Sophiatown (Johannesburg), South End (Port Elizabeth) and Lady Selborne (Pretoria), to mention only a few. Contrary to popular notion that District Six was an ill-begotten, crimeinvested urban slum (Field 2001), Jeppie and Soudien (1990:203), described it as the 'birthplace of the national democratic movement and the fountainhead of literature, intellectual and ideological development in South Africa'. This statement is equally valid if applied to other communities that were destroyed by forced removals. These communities have deliberately been stereotypically represented as ridden with gangsters, alcoholism and crime, deserving of destruction (Schoeman 1994; Van Tonder 1990).

This project is a work in progress with the purpose of reconstructing a more inclusive narrative of District Six, thereby restoring the dignity of the historically oppressed by giving voice to their suppressed memories and untold stories. While District Six and forced removals feature prominently in academic publications, a common research objective was to preserve the past and to remember the injustices of the apartheid government (Carrim 1990; Field 2001; Trotter 2009). Needless to say, a number of monographs and academic theses have been produced on forced removal communities, which created a rich literature source. Noteworthy literature on District Six includes Hart (1990), Field (2001) and Jeppie and Soudien (1990). On Fietas' (Johannesburg) history, the works of Carrim (1990) and Okunlola (2013) are important. About South End in Port Elizabeth, the writings of Hendricks (2017) and Agherdien, George and Hendricks (1997) deal comprehensively with forced removals. Lady Selbourne has been recorded expansively by Mojapelo (2008), while Sophiatown was the subject of research in Van Tonder's Master's thesis (1990) and Hart's doctoral dissertation (1990). While the extant literature demonstrates the disciplinary nature of available knowledge, this project shows the epistemological value of adopting a transdisciplinary approach when excavating the unrecorded and marginalised histories of a forgotten community.

Transdisciplinary research differs from traditional research as it crosses disciplinary boundaries that govern academic inquiry. Augsburg employs Nicolescu's concept of a 'transdisciplinary attitude' to describe the intellectual disposition adopted by researchers involved in transdisciplinary projects (Augsburg 2014:233). Nicolescu asserts that transdisciplinary education has its origins in the richness of the scientific spirit, which is based on questioning the a priori answers and certitude contradictory to the facts (Nicolescu 1999). A transdisciplinarity attitude revalues the role of deeply rooted intuition, of imagination, of sensitivity and of the body in knowledge production (Nicolescu 1999). Despite the abundant literature available on District Six, this project is guided specifically to target those topics that have not been researched such as, inter alia, untold life story histories (the late Salie Fredericks, rugby legend), John Hendricks (hymn composer and choir master), institutional biographies (Moravian Zinzindorf Primary School, Sheikh Joseph Moslem Primary School), cultural and religious communities (Qanimia Indian community, Mohamadi Qadiri Jama and Moravian congregation) and sport clubs (Collegians, Rosendales and Roslyns Rugby clubs). In the reconstruction of the historical narrative, an embodied notion of knowledge, as suggested by Nicolescu (1999) becomes a meaningful alternative as a possible decolonising approach to research. Nicolescu's embodied notion of knowledge is embedded in the concept of transdisciplinary as a perspective that involves collaborative research from a myriad of professions, disciplines and societal sectors. Collaborators would creatively co-generate new knowledge that has personal meaning to them: an expression of growing their 'transdisciplinary self' (McGregor 2015:9). Embodied knowledge is understood to involve inner changes that allow the researcher to grow into a new and progressively, more complex self.

In addition to identifying the epistemological gap in current District Six literature, this project became the genesis of a transdisciplinary research journey that resulted in theorisation across the spatiotemporal forced removal landscape in South 
Africa. In an effort to make history responsive to contemporary challenges facing post-apartheid society, the project generated innovative perspectives on forced removals by engaging dynamics of gentrification, drawing similarities between forced removals and gentrification as a form of post-apartheid, neo-liberal, people displacement. The project also excavated intergenerational memories of forced removals that shaped the identities and knowledge of a group of learners with ancestral roots in District Six (Davids 2017).

\section{Conceptual framework}

While individual researchers conduct their research independently, they participate collaboratively in a common project. For the purpose of this article, the author employs the concepts 'self-reflective historiography', 'decoloniality' and 'transdisciplinarity' as conceptual framework. Selfreflective historiography is employed as a key component in an auto-ethnographic narrative. In this project, the author's subjective experiences and knowledge of the context shape the architecture of the project. Borrowing Foucault's notion of biopower (Pylypa 1998), the 'self' is expressed in the context of complex discursive practices, which make expressions fluid and unpredictable. The self is embodied (Nicolescu 1999) and the body is entangled in power relations, which render it docile but potentially productive. The productive body uses the power of technology of self in expressing knowledge in the form of disciplinary discourses (Smart 2002:76). In this study, the author's self-reflexivity becomes productive as he asserts power in challenging existing disciplinary boundaries that became the basis for existing knowledge.

The second component of the conceptual framework is 'decoloniality'. According to Raewyn Connell (2016), the continuation of hegemonic forms of knowledge in the global economy has been maintained by the power of 'coloniality'. Frantz Fanon (1925-1961) pointed out that colonisation does not only take place through political and economic processes of domination but also through cultural and linguistic alienation, leaving an indelible imprint on the psyche of the colonised subject (Satpathy n.d.). It was Ngugi wa Thiong O who suggested that the decolonisation of the mind becomes crucial to the emancipation of colonial subjects from the effects of colonialism especially after power was transferred to the colonised (Satapathy n.d.:28). The term 'decolonisation' has multiple meanings and cannot be used monolithically. In Southern Africa, the decolonisation process unfolded differently in Namibia, Zimbabwe and the Portuguese colonies (Angola, Mozambique). To explain the case of South African colonisation, the African National Congress (ANC) used the phrase 'colonialism of a special type' (ANC 1987:1). What was special about the colonial system in South Africa was that there was no spatial separation between the colonising power (white minority state) and the colonised black majority. Another feature of the South African case is that the apartheid state was independent of any colonial power, having a sovereignty legally vested in them by various Acts of the British government and state (ANC 1987:1). Colonisation lasted for 342 years (1652-1994) before an independent democratic state was established, but the colonial values and mindset arguably continue. In South Africa, coloniality and the need to 'decolonise the mind' came to a wild awakening when in 2015, university students initiated a national protest movement for free, decolonised and quality education. Students experienced their education as alienating, Eurocentric and entrenching a Western hegemonic epistemology (Fataar \& Subreenduth 2015). Despite Africa's political severance from their colonial histories for more than 50 years, the institutionalising effects of colonisation on the epistemic and socio-economic structures of societies are reproduced in various forms (Fataar \& Subreenbuth 2015).

South Africans, as revealed in this study, are not free from the manifestation of 'coloniality'. An example of coloniality is the theatrical work on District Six by the late Taliep Petersen. Sauls argues that Petersen and David Kramer portrayed District Six as mainly a place of 'gangsters, an uneducated class, illiterate and lazy hooligans hanging out on street corners' (Sauls 2004:39). These derogatory themes are colonial representations but remained dominant in Petersen and Kramer's productions such as District Six: The Musical; Fairyland; Crooners; Poison; and Kat and the Kings. In Kramer's 2016 production: District Six - Kanala, negative stereotypes are again reproduced. These images of District Six are consistent with the apartheid-colonial representation of black (African) colonised people as inferior and insignificant (Alvares 1991). Revising the existing historical narrative requires a decolonising lens to promote an emancipatory sense of being which may be offered in a multi-perspective, transdisciplinary approach to research.

Transdisciplinarity is the third component in the conceptual framework. In conjunction with the primacy of the role of an 'embodied self', Nicolescu argues that the 'subject' transcends the 'object' in transdisciplinary research and that the subject cannot be encamped in a restricted discipline (2010:22). Nicolescu (2010) defines multidisciplinarity as a concern with studying a research topic in several disciplines simultaneously, while interdisciplinarity refers to the transfer of methods from one discipline to another. Transdisciplinarity is research among, across and beyond various disciplines (Nicolescu 2010:22). Van Eeden (2010) developed a notion of transdisciplinarity based on Nicolescu's understanding. For the purpose of this study, Van Eeden's (2010) model of transdisciplinarity provides a clear path to identify stages in the research process. Van Eeden (2010) asserts that one cannot move towards a transdisciplinary approach without recognising the disciplinary nature of a field of study. From a disciplinary position, the researcher moves towards interdisciplinary fields where there is an overlap of disciplines and eventually the transdisciplinary, which is the third phase (Van Eeden 2010:194). Van Eeden worked from a history disciplinary orientation, which presupposes the availability of knowledge, memories and primary resources. The incorporation of knowledgeable people, coming from different disciplinary fields, in a multidisciplinary research project, 
qualifies a project to be labelled as a transdisciplinary project (Van Eeden 2010). In the District Six project, transdisciplinary research is incorporated by multidisciplinary researchers from, inter alia, history, environmental studies, technology education and religious studies. These researchers agreed to write scientific articles as research outputs and to share conference panel discussions. The District Six project can be categorised as transdisciplinary, according to Van Eeden's three-phase model, because it moved from its initial historybased discipline to its eventual transdisciplinarity stage.

As a case study, District Six remains rich in unexplored and suppressed cultural memory and history. Based on the assessment of this project as a transdisciplinary study, this article is ontologically informed by the author's use of selfreflective historiography and technology of self by having interwoven his knowledge and experience of District Six and forced removals.

\section{Objectives of the study}

The objectives of this study are twofold: firstly to argue that this project qualifies as a transdisciplinary case study and, secondly, to demonstrate the epistemological generativity and productivity of a transdisciplinary approach as a knowledge-producing methodology. The article unfolds as follows: research design, data presentation and analysis, discussion and conclusion.

\section{Research design}

The research design for this article is informed by two research questions: firstly, how was transdisciplinarity manifested in a project initially conceived as a history study? Secondly, in the context of decolonisation, what useful epistemology emerged from this project? The next section is subdivided into the research design and data presentation and analysis.

This article employs a qualitative, auto-ethnographical, transdisciplinary, instrumental case study design. Methodologically, Nicolescu (2010) argues for a unitary notion of reality that includes the subject, object and the hidden third. The latter refers to the interaction between the subject and the object (Nicolescu 2010:19). Nicolescu argues that transdisciplinarity is both unified and diverse: unity in diversity and diversity through unity. Nicolescu speaks about phenomenological transdisciplinarity as one type of transdisciplinarity that focuses on the lived experiences of the subject in the research. As a former District Six resident and author, I prefer to use the more commonly-known method of auto-ethnography because this project is inextricably part of my sense of being. The study is qualitative with its focus on the subjective experiences of individuals and their interaction with context. Project proposal texts serve as evidence of disciplinary content and dispositions. The author played the role of researcher, coordinator and narrator when he brought to bear his own interpretations and cultural orientations on the project (Goldbart \& Hustler 2005:16).
As a case study, this project is bounded by space and time (Mabry 2009): District Six and apartheid forced removals. Guba and Lincoln (1981) classified case studies into a number of types, differentiating between those that are descriptive, interpretive and evaluative. This is an evaluative, instrumental case study, which is used to accomplish something more than understanding a particular situation (Nieuwenhuis 2016:82). In this study, the District Six project became instrumental in demonstrating how transdisciplinarity was used as a research approach to provide insights and new knowledge (Nieuwenhuis 2016:82). Van Eeden's (2010) three-phased disciplinary model was employed to differentiate between the project in its initial stages and in its growing complexity to an advanced transdisciplinary phase.

\section{Data presentation and analysis}

Before presenting an analysis of the project proposal texts, a brief note on the sample, data collection and analysis is explained. A sample of three Masters students' and seven academic proposals were deemed as data and potential research outputs. These proposals were analysed textually and thematically to glean their transdisciplinary characteristics. Textual contents were analysed based on titles, disciplines, theoretical frameworks and methodologies. Content analysis is 'any technique for making inferences by objectively and systematically identifying specified characteristics of messages' (Nieuwenhuis 2016:111). Analytical categories were colour-coded for easy identification.

Another source of data was the author as auto-ethnographical narrator and participant researcher. The researcher became a 'complete participant' when he immersed himself in the setting of a project, to the extent that other participants did not know that they were the participants of the observation (Nieuwenhuis 2016). Although all participants became voluntary participants, individual consent to use the proposals or abstracts as textual data was given. All of them will become authors in the research output: proposed book publication.

\section{Results and discussion Data analysis 1: Titles and disciplines}

Three Master's students were registered at one university, in three different colleges: Environmental Science, Education and Human Sciences (Religious Studies). After registration, they submitted their proposal drafts. In addition, six project proposals were received from academics in which they located their disciplinary positions in the context of the project. The proposals submitted were identified as belonging to the following disciplines or sub-disciplines: Life story history or biographical studies, history, environmental geography, technology education and town planning. The project was launched at a national conference panel discussion. Three workshops and individual meetings were held for consultation and sharing. Table 1 summarises the titles, disciplines or sub-disciplines and format of the proposed research output. 
TABLE 1: Titles, disciplines or sub-disciplines and outputs.

\begin{tabular}{|c|c|c|}
\hline Preliminary titles & $\begin{array}{c}\text { Discipline/ } \\
\text { sub-disciplinary field }\end{array}$ & $\begin{array}{l}\text { Publication format/proposed } \\
\text { output/institutional affiliation }\end{array}$ \\
\hline $\begin{array}{l}\text { The history of Chapel } \\
\text { Street Primary: Educational } \\
\text { change from colonial to } \\
\text { the end of apartheid }\end{array}$ & $\begin{array}{l}\text { History: History of } \\
\text { Education }\end{array}$ & $\begin{array}{l}\text { M.Ed. dissertation/Book } \\
\text { chapter } \\
\text { Ms Sakeenah Davids-Soeker } \\
\text { (Student at the University of } \\
\text { South Africa) }\end{array}$ \\
\hline $\begin{array}{l}\text { Residential Mobility and The } \\
\text { Well-Being of Displaced } \\
\text { Students: A Case Study of } \\
\text { Cape Town's Inner-City } \\
\text { Suburbs, District Six, Salt } \\
\text { River and Woodstock }\end{array}$ & $\begin{array}{l}\text { Environmental } \\
\text { Studies }\end{array}$ & $\begin{array}{l}\text { MSc dissertation/Book } \\
\text { chapter } \\
\text { Ms Naeemah Sadien (Student } \\
\text { at the University of South } \\
\text { Africa) }\end{array}$ \\
\hline $\begin{array}{l}\text { Indian Muslims in District } \\
\text { Six: From settlement } \\
\text { to forced removals - } \\
\text { 1860-1966 }\end{array}$ & Religious Studies & $\begin{array}{l}\text { M.A. dissertation/Book } \\
\text { chapter } \\
\text { Nazeem Khan (Student at the } \\
\text { University of South Africa) }\end{array}$ \\
\hline $\begin{array}{l}\text { District Six subaltern voices } \\
\text { and the rise of town } \\
\text { planning as a practice }\end{array}$ & $\begin{array}{l}\text { Town Planning/ } \\
\text { Computer Technology } \\
\text { Architecture }\end{array}$ & $\begin{array}{l}\text { Book chapter } \\
\text { Dr F. Gierdien (Stellenbosch } \\
\text { University) }\end{array}$ \\
\hline $\begin{array}{l}\text { Formal Muslim education in } \\
\text { District Six: Sheikh Joseph } \\
\text { Primary School as a case } \\
\text { study }\end{array}$ & $\begin{array}{l}\text { History/History of } \\
\text { Education }\end{array}$ & $\begin{array}{l}\text { Book chapter } \\
\text { Dr M.N. Davids (University of } \\
\text { South Africa) and } \\
\text { Dr E. Behardien (Researcher) }\end{array}$ \\
\hline $\begin{array}{l}\text { Missionary education in } \\
\text { District Six: From Moravian } \\
\text { Hill to Zinzindorf Primary } \\
\text { School }\end{array}$ & $\begin{array}{l}\text { History: Church } \\
\text { History and Education }\end{array}$ & $\begin{array}{l}\text { Book chapter } \\
\text { Dr M. Van Breda (University of } \\
\text { Cape Town) and Dr M.N. } \\
\text { Davids (University of South } \\
\text { Africa) }\end{array}$ \\
\hline $\begin{array}{l}\text { Re-telling the life history of } \\
\text { Salie Fredericks as a rugby } \\
\text { legend }\end{array}$ & $\begin{array}{l}\text { Life history research: } \\
\text { biography }\end{array}$ & $\begin{array}{l}\text { Book chapter } \\
\text { Dr O. Esau (Stellenbosch } \\
\text { University) and Dr M.N. } \\
\text { Davids }\end{array}$ \\
\hline $\begin{array}{l}\text { Challenging dominant } \\
\text { narratives through digital } \\
\text { storytelling: student } \\
\text { narratives of District Six }\end{array}$ & $\begin{array}{l}\text { Technology } \\
\text { education: digital } \\
\text { storytelling and } \\
\text { literacy }\end{array}$ & $\begin{array}{l}\text { Book chapter } \\
\text { Dr Daniella Cagocha and Ms } \\
\text { Alex Noble (Cape Peninsula } \\
\text { University of Technology) }\end{array}$ \\
\hline $\begin{array}{l}\text { The making of a hymn writer } \\
\text { and choir master: the life } \\
\text { story of John Hendricks } \\
\text { (New Apostolic Choir) }\end{array}$ & $\begin{array}{l}\text { Life history research: } \\
\text { a phenomenological } \\
\text { case study }\end{array}$ & $\begin{array}{l}\text { Book chapter } \\
\text { Dr K. Dos Reis (University of } \\
\text { the Western Cape) and Dr M. } \\
\text { N. Davids (University of South } \\
\text { Africa) }\end{array}$ \\
\hline $\begin{array}{l}\text { Proposed monograph based } \\
\text { on author's research on } \\
\text { District Six: District Six and } \\
\text { other forced removal } \\
\text { memories: from 'Ubuntu' to } \\
\text { 'Cosmubuntuism' as a } \\
\text { prototype model for } \\
\text { democratic South Africa }\end{array}$ & $\begin{array}{l}\text { History and } \\
\text { transformation: } \\
\text { decolonising } \\
\text { methodologies, } \\
\text { pedagogy }\end{array}$ & $\begin{array}{l}\text { Monograph: various chapters } \\
\text { Dr M.N. Davids (University of } \\
\text { South Africa) }\end{array}$ \\
\hline $\begin{array}{l}\text { The work of the Muhamadi } \\
\text { Qadiri Jama ( } 1952 \text { to the } \\
\text { present) - Expansion of } \\
\text { Islam in the Cape Flats }\end{array}$ & Religious Studies & $\begin{array}{l}\text { Book chapter } \\
\text { Dr M.N. Davids (University of } \\
\text { South Africa) and Ms Shifah } \\
\text { Abrahams (Researcher, } \\
\text { student at the University of } \\
\text { Cape Town) }\end{array}$ \\
\hline
\end{tabular}

\section{Data analysis 2: Theoretical frameworks}

This section takes a closer look at the theoretical or conceptual frameworks that were implicitly or explicitly identified in the proposal texts. The proposals are available for verification and kept under secured conditions according to standard research practice.

\section{Critical historical theory}

Three proposals reflected the use of 'historical theory'. These proposals deal with three educational institutions of which two: Moravian Zinzindorf Primary and Sheikh Joseph Moslem Primary School have been demolished during the time of forced removals. A third, Chapel Street Primary School, has a long history since 1845 and is still in operation. Critical thinking is an approach to interpreting content that generates new thoughts, understandings and beliefs to create instruments of insight and a new point of view (Lunenburg 2011). The authors brought to their conceptual underpinnings a strong critical orientation. They were either personally connected with the institution or have intimate knowledge of people associated with the institutions. According to one of the proposals, the purpose of the study is to excavate and record the forgotten areas of social life of parts of the community of District Six, which implies a critical grassroots perspective of history. Preserving the memories of these institutions as official history would have been detrimental to the apartheid regimen as they would remind the nation of the injustices committed against the oppressed. The deliberate exclusion of the people's history from the official curriculum is now being addressed and with the transition to democracy, a more inclusive, fuller history of the nation would have to replace prevailing knowledge imbalances. These proposals have a definite contribution to make to District Six's memory. These proposals depart from a theoretical framing that interprets education from a functional perspective and pursue a critical understanding of apartheid education.

\section{Subaltern theory}

'Giving voice to the oppressed' emerged as a commonly used phrase in many texts. The project instilled an intellectual concern to challenge the dominant Eurocentric, colonial historiography of District Six. Hence, a counter, decolonised narrative that intersects with culture, arts and ethics became a project objective that permeated the proposals. Authors used the term 'subaltern' with reference to the oppressed classes who were denied positive or appropriate recognition during apartheid. The use of the term 'subaltern' seems to deviate from Gramsci's notion of the subaltern as 'proletariat' because the voices of not only the poor but also the famous middle and lower middle-class achievers in District Six were suppressed (Chaturvedi 2007:9).

\section{Critical race theory}

Another strand of theory identified in the proposals is critical race theory, which is innovatively used in a digital storytelling proposal. The proposal seeks to reconstruct the dominant narratives on District Six. The proposal's objective is to disrupt stereotypical historical narratives by engaging with the past and the present. Decolonisation is an underlying epistemological objective of the proposal as the study will pursue counter-narratives and critical thinking to produce socially conscious students as future leaders. While critical race theory is primarily associated with legal studies, its methodology is increasingly gaining popularity in social studies, especially where race, class and ethnicity form an integral part of the social context (Lynn \& Dixson 2013). Given the historical role of race in education, critical race theory offers useful analytical lenses to expose hidden meanings not often revealed through commonly used functional theories.

\section{Spatial theory}

Spatial theory emerged in four proposals in three different disciplines: town planning and architecture of urban renewal initiatives, gentrification, segregation history and forced removal policies, and place-making of Indians in District 
Six (1860-1980). In the empire's grand plan to develop Cape Town as a modern city, District Six was neglected in spatial planning and it appeared that the place was intended for demolition in the future. Some proposals revitalise the town planning history debate by asking whether the City of Cape Town's urban renewal initiatives in the post-apartheid period were a continuation of apartheid and market-driven policies that led to the residential displacement in Woodstock and Salt River, similar to that of District Six during and before apartheid. With reference to various forced removal case studies (District Six, Sophiatown, Fietas, South End and Lady Selborne), spatial theory is applied to explain the systematic establishment and subsequent destruction of communities for ideological and economic reasons. Spatial theory challenges traditional economic determinist explanation by inserting the role of human agency which in this case was demonstrated by the segregation ideology of the British and apartheid policy of Afrikaner nationalists.

\section{Phenomenological theory}

One study employed phenomenology as practical theory to describe the making of a 'hymn writer' and 'choir conductor'. Phenomenology is concerned with the study of experiences from the perspective of the individual, where personal knowledge and subjectivity are emphasised as data for interpretation (Hefferon \& Ollis 2006). Findings emerge as the subject's mind is opened and probed for rich descriptions of personal experiences. This proposal is underpinned by the project objective to recognise the unsung heroes who were ignored because they belonged to the subaltern class. Given the centrality of probing the lived experiences in a phenomenological study, this theoretical approach is well placed to produce new knowledge that will contribute towards unfolding of a rich historical kaleidoscope.

\section{Data analysis 3: Research methodologies}

A meta-analysis of the project research designs revealed an overwhelming use of qualitative research methodologies. This is in line with any transdisciplinary study that places the subject at the centre of analysis (Nicolescu 2010). Transdisciplinarity departs from a classical positivistic science by seeking to develop an intellectual perspective that bridges the gap between human and nature, a rejection of an objective view of knowledge (Nicolescu 2010).

\section{Ethnomethodologies}

Qualitative methods pursue to study the meaning of subjective experiences and interactions of individuals in their contexts. Qualitative research recognises the complexity of human meaning. A major strand of qualitative research identified in the proposals is variation of the 'ethnomethodological' approach to data collection. Ethnomethodology was developed by Garfinkel (1984) and focuses on 'reflexivity' that carries out technologies of self in the representation and creation of everyday life activities. In one proposal, the interview technique is proposed to probe the memories and experiences of former learners of Sheikh Joseph Moslem Primary School. These interviews will produce data that will be used in tandem with historical constructions based on archival material and documents. Similarly, the proposal on Chapel Street Primary school also proposes to use the same methodological approach. The proposal dealing with Residential Mobility and Wellness involves the identification of stakeholders through desktop analysis, archival research and retrieving memorialised as well as living ethnographic materials of displaced residents from District Six and Woodstock.

\section{Archival searches and documents}

In most of the proposals, reference is made to archival searches to establish the historical veracity of their study focus and to construct narratives based on documentary evidence. Archives are being searched because any attempt at (re)writing history requires the visitation of the archives. Documents were extracted from institutions such as the District Six Museum, Wynberg Education Museum, Cape Provincial Archives and the Moravian Theological College archives. Documents represent power over memory and identity and serve as a source for historical narrative (Schwartz \& Cook 2002). Proposals drew on archives or documents to reconstruct institutional histories (Moravian, District Six Indian community, Sheikh Joseph's School and Chapter Street Primary school). The approach to archives and documents is motivated by the quest to find new meanings in light of possible biased interpretations. Needless to say, these studies will potentially offer new sources that will enrich existing literature.

\section{Interviews}

The interview technique lies at the heart of investigating how people behave, experience and understand. In some proposals, the interview technique is proposed to bring out the 'voice' of the people. According to Cohen, Manion and Morison (2007), the interview is a valuable method for exploring the construction and negotiation of meanings in a natural setting. The interview emerged as the spinal method in those proposals identified as ethnographic and phenomenological. Interviews yield experiential knowledge, which become the data to (re)tell stories and (re)construct spatial and temporal meanings. Most proposals intended to use the structured and semi-structured interview. The semistructured interview shows more flexibility than the structured interview and allows for the interviewee to be probed for deeper responses (Berg 2007).

\section{Discussion}

The data analyses identified a myriad of proposal titles across disciplines, employing diverse theoretical or conceptual frameworks and methodological designs. Titles bring together disciplines across colleges and theoretical and conceptual frameworks from various critical traditions. Overwhelmingly, qualitative data collection techniques such as the interview, archives and documents, and reflexivity were identified. The 
diversity in disciplinary approaches was bounded by the broad objectives of the project, which intends to produce knowledge with an essentially different architecture: a correction of the epistemic injustice of the past (Fataar \& Subreenduth 2015) and the centrality of an 'embodied subject' in knowledge construction (Nicolescu 1999).

With reference to the first research question, the transdisciplinary nature of this project was displayed in the various proposals that contributed to deepen an understanding of the project theme. As a transdisciplinary project, the different disciplines or sub-disciplines were united on an understanding that transdisciplinary knowledge brings unity through diversity (Nicolescu 2010). This project traces the emergence of its transdisciplinarity since its genesis as a historical study and its development towards a complex amalgamation of disciplines. Initially a history project, the first shift took place when students' proposals were submitted to different colleges. Van Eeden's (2010) three-phase model provides a conceptual trajectory to trace the project's progression from asking a simple historical question to the formulation of research questions from multiple disciplines.

As for the second research question - the epistemological value of a transdisciplinarity research approach - a collective evaluation of the project proposal shows the potential of emerging decolonised and contextually meaningful knowledge claims (Fataar \& Subreenduth 2015). All proposals addressed the need to 'decolonise the mind' (Killam 1984) and to bring out the voices of the subaltern (Chaturvedi 2007). Pedagogically, the project's research outputs are destined to make substantive contributions to new knowledge, which will provide learning material for educational institutions locally and nationally.

Transdisciplinary research begins with an attitude (Nicolescu 1999) that goes beyond one discipline. It is therefore suggested that interdepartmental research be explored among academics and as in this case study, postgraduate studies be explored across universities, colleges or faculties and departments with possibilities for co-supervision. The three Master degrees that form part of this project are registered in three different colleges and co-supervised by academics in different colleges. The promotion of transdisciplinary research begins with a discipline-based study towards the incorporation of interdisciplinary projects, which gradually becomes transdisciplinary (Van Eeden 2010).

\section{Conclusion}

The District Six project and transdisciplinarity complement each other in a symbiotic way. There seems to be a common concern to excavate the voices of the historically oppressed in the District Six project, which corresponds with the centrality of placing the 'voice' of the subject in, as opposed to outside the research in transdisciplinarity (Nicolescu 2010). Authentic, embodied knowledge is arguably a common pursuit of the project and transdisciplinary research.
This article is an evaluative study of an NRF history project that evolved into a transdisciplinary study. An objective of the project is to excavate unknown, suppressed and forgotten knowledge of District Six to be used for epistemological reconstruction. Project proposal texts serve as evidence that research conducted with a transdisciplinary attitude (Nicolescu 1999) can be productive and generative. An innovative conceptual-methodological framework evolved while engaging with the complexity of the demand for a decolonised curriculum (The Salon 2015). This defining characteristic of the project was incorporated in all the proposals as an underlying epistemological objective. As a work in progress, a few journal articles have already been published (Davids 2015; 2017), while three registered Masters students are expected to submit their dissertations in 2018-2019. Various book chapters are at their advanced stage of completion. As a qualitative, autoethnographic, instrumental case study, the District Six project to date has demonstrated the epistemological value of adopting a transdisciplinary research approach (see Table 1).

In the same way that District Six is in need of alternative historical narratives, transdisciplinarity searches for an alternative understanding of reality. Transdisciplinarity places the subject or researcher at the heart of the knowledge production process, which provides a viable philosophical alternative that is productive as it encourages questioning beyond disciplinary boundaries. The transdisciplinary ethic seeks to establish sustainable development and sustainable futures (Nicolescu 2010:35) by seeking a new philosophicalintellectual orientation to reality that speaks of the unity and diversity of disciplines: unity in diversity and diversity through unity (Nicolescu 2010:23). The South African coat of arms: '!ke e: / xarra / / ke': 'diverse people unite', which is a precolonial Khoisan expression, makes transdisciplinarity potentially an Ubuntu science. Ubuntu rejects the artificial separation of humans into 'races' (Tutu 1999) in the same way that transdisciplinarity rejects researching 'human' and 'nature' separately. While the District Six project may soon come to an end, its essence will be kept alive by the numerous unanswered questions that the project will generate through its transdisciplinarity.

\section{Acknowledgements}

The author would like to acknowledge the funding and support received from the National Research Foundation of South Africa to conduct the research for this project. The author would also like to extend his heartfelt thanks to all the participating students, authors and co-authors from the University of Cape Town, Stellenbosch, Cape Peninsula University of Technology and the University of the Western Cape.

\section{Competing interests}

The author declares that he has no financial or personal relationship(s) that may have inappropriately influenced him in writing this article. 


\section{References}

African National Congress (ANC), 1987, Apartheid South Africa: Colonialism of a special type, viewed 09 March 2018, from http://www.anc.org.za/content/ apartheid-south-africa-colonialism-special-type

Agherdien, Y., George, A.C. \& Hendricks, S., 1997, South end- as we knew it, Western Research Group, Port Elizabeth.

Alvares, C., 1991, Decolonising history: Technology and culture in India, China and the West, 1492 to present day, The Other India Press, Goa, India.

Augsburg, T., 2014, 'Becoming transdisciplinary: The emergence of the transdisciplinary individual', World Future 70, 233-247. https://doi.org/10.1080/02604027.2014.9 34639

Berg, B.L., 2007, Qualitative research methods for the social sciences, Pearson, London.

Carrim, N., 1990, Fietas - A social history of pageview: 1948-1988, Save Pageview Association, Creda Press, Johannesburg.

Chaturvedi, V., 2007, 'A critical theory of subalterity: Rethinking class in Indian historiography', Left History 12(1), 9-28.

Cohen, L., Manion, L. \& Morison, K., 2007, Research methods in education, 6th edn., Routledge, London.

Connell, R., 2016. Decolonising Knowledge, Democratising Curriculum. A discussion on Decolonisation of Knowledge at the University of Johannesburg, March 2016.

Davids, M.N., 2015, 'The history of collegians rugby club's survival: From apartheid to democracy', Journal for Contemporary History 41(1), 144-161.

Davids, M.N., 2017, 'Using memory work as a decolonizing pedagogy in a study on District Six's forced removal history: A case for epistemic justice', Journal of Education 69, 93-116.

Dreyfus, H.L. \& Rabinow, P., 1982, Michel Foucault: Beyond structuralism and hermeneutics, The University of Chicago Press, Chicago, IL.

Fataar, A. \& Subreenduth, S., 2015, 'The search for ecologies of knowledge in the encounter with African epistemicide in South African education', South African Journal of Higher Education 29(2), 106-121.

Field, S., 2001, Lost communities, living memories: Remembering forced removals in Cape Town, Memory, Knowledge and Power: Can Archives Keep People, David Philip, Cape Town

Foucault, M., 1991, Discipline and punishment: The Birth of the prison, Penguin, London.

Garfinkel, H., 1984, Studies in ethnomethodology, Polity, Cambridge.

Goldbart, J. \& Hustler, D., 2005, 'Ethnography', in B. Somekh \& C. Lewin (eds.) Research methods in the social sciences, pp. 16-23, Sage, London.

Guba, E.G. \& Lincoln, Y.S., 1981, Effective evaluation, Jossey-Bass, San Francisco, CA.

Hart, D.M., 1990, 'Master plans: The South African Government's razing of Sophiatown, Cato Manor and District Six', Partial fulfilment of the Doctor of Philosophy in Geography, Graduate School of Syracuse University.

Hefferon, K.M. \& Ollis, S., 2006, “Just clicks": An interpretive phenomenological analysis of professional dancers' experiences of flow', Research in dance Education analysis of professional dancers' experiences of flow', Research
$7(2), 141-159$. https://doi.org/10.1080/14647890601029527

Hendricks, S., 2017, 'Biography of a vanished community: South End, Port Elizabeth', Unpublished PhD thesis, University of Stellenbosch.

Hunter, Q., 2017, 'Free higher education will be fiscally sustainable, says Zuma', Sunday Times, 16 December, viewed 08 May 2018 from https://www.timeslive. co.za/politics/2017-12-16-free-education-needs-improved-governmentspending-cosatu/

Jeppie, S. \& Soudien, C., 1990, The struggle for District Six: Past and present, Buchu Books, Cape Town.

Killam, G.D., 1984, Critical perspectives on Ngugi wa Thiong'o, Three Continents Press, Washington, DC
Langa, M., 2017, \# Hashtag: An analysis of the \#FeesMustFall Movement at South African universities, Center for the Study of Violence and Reconciliation, Johannesburg.

Lunenburg, F.C., 2011, 'Critical thinking and constructivism techniques for improving student achievement', National Forum of Teacher Educational Journal 21(2), 1-9.

Lynn, M. \& Dixson, D., 2013, Handbook of critical race theory in education, Routledge, New York.

Mabry, L., 2009, 'Case study in social research', in P. Alasuutari, P. Sickman \& J. Brannen (eds.), The Sage handbook of social research methods, pp. 214-227, Sage, London.

McGregor, S.L.T., 2015, Transdisciplinary knowledge creation, Mount Saint Vincent University, Halifax, NS.

Mignolo, W., 2009, 'Epistemic disobedience, independent thought and de-colonial freedom', Theory, Culture, \& Society 26(7-8), 1-23.

Mojapelo, J.S., 2008, The corner people of lady Selborne, University of South Africa, Pretoria.

Nicolescu, B., 1999, 'The transdisciplinary evolution of learning', in Symposium on Overcoming the Underdevelopment of Learning at the Annual Meeting of the American Educational Research Association, Montreal, Canada, viewed 09 October 2017, from http://perso.club-internet.fr/nicol/ciret

Nicolescu, B., 2010, 'Methodology of transdisciplinarity - Levels of reality, logic and the included middle and complexity', Transdisciplinary Journal of Engineering \& Science 1(1), 19-38.

Nieuwenhuis, J., 2016, 'Qualitative research designs and data-gathering techniques', in K. Maree (ed.), First steps in research, pp. 49-70, Van Schaik Publishers, Pretoria.

Okunlola, O., 2013, 'Memories of Fietas from the Late 50s to the 70s', in C. Landman (ed.), Oral history: Representing the hidden, the untold and the veiled, pp. 65-83, Research Institute for Theology \& Religion, University of South Africa, Pretoria.

Pylypa, J., 1998, 'Power and bodily practice: Allying the work of Foucault to anthropology of the body', Arizona Anthropologist 13, 21-36.

Satpathy, P.K., n.d., Post-colonial literature: Africa: Things fall apart and decolonizing the mind, School of Open Learning, University of Delhi, viewed 15 October 2017, from https://www.google.com/search?sourceid=navclient\&ie=UTF-

Sauls, R.K., 2004, 'Identity: A study of representation with reference to District Six', A dissertation submitted in partial fulfilment of the degree of Master of Fine Arts, Humanities, University of Cape Town.

Schoeman, C., 1994, District six: The spirit of Kanala, Human \& Rousseau (Pty) Ltd, Cape Town.

Schwartz, J.M. \& Cook, T., 2002, 'Archives, records and power: The making of modern memory', Archival Science 2, 1-19. https://doi.org/10.1007/BF02435628

Smart, B., 2002, Michel Foucault, Routledge, London.

The Salon, 2015, “UCT Rhodes must fall mission statement', vol. 9, viewed 05 July 2017, from www.jwtc.org.za/resources/docs/salon-volume9/RMF_Combined.pdf

Trotter, H., 2009, 'Trauma and memory: The impact of apartheid-era removals on coloured identity in Cape Town', in M. Adhikari (ed.), Burden by race: Coloured identities in Southern Africa, pp. 49-78, UCT Press, Cape Town.

Tutu, D., 1999, No future without forgiveness, Penguin, London.

Van Eeden, E.S., 2010, 'Using a transdisciplinary approach for environmental crisis research in history', The Journal for Transdisciplinary Research in Southern Africa 6(1), 191-208. https://doi.org/10.4102/td.v6i1.127

Van Tonder, D.P., 1990, 'Sophiatown: Removals and protest 1940-1955', Unpublished Master of Arts thesis, University of South Africa, Pretoria.

Visser, W., 2004, 'Trends in the history of South African historiography and the present state of historical research', Paper presented at the Nordic Africa Institute, University of Stellenbosch, Uppsala, Sweden, 23 September 2004.

Wright, H.M., 1977, The burden of the present: Liberal-radical controversy over Southern African history, David Philip, Cape Town. 